\title{
Die betekenis van Lukas 13:10-17 en 2 Korintiërs 12:1-10 vir die okkultisme-diskoers
}

\author{
Johan Janse van Rensburg \\ Departement Diakoniologie \\ Universiteit van die Vrystaat \\ BL.OEMFONTEIN \\ E-pos: janvanrenj@stig.uovs.ac.za
}

\begin{abstract}
Some implications of Luke 13:10-17 and 2 Corinthians 12:1-10 for the debate on the occult

In the past the dehate concerning the occult has been dominated by the question "Is it possible that a Christian can he occully plagued?" While one interpretation of Luke 13:10-17 suggests that it is possible, another interpretation of this passage from Scripture suggests that such a conclusion drawn from Luke 13 would be incorrect How'ever, the article suggests that subjective points of view' may influence and mar the scientific approach to the exegesis of Luke 13. The article attempts to evaluate exegetic commentaries in an objective manner while also inquiring into the relevance of 2 Corinthians 12.1-10 for the issue under debate. Some conclusions for pastoral care and counselling are derived from the conclusions.
\end{abstract}

\section{Probleemstelling}

Die teologiese diskoers oor demoniese bindinge word jare reeds deur 'n bepaalde interpretasie van Lukas 13:10-17 oorheers. Enersyds word dié teks gebruik om te bewys dat gelowiges gebind kan wees, maar andersyds ontken sommige teoloë dat só 'n afleiding gemaak kan word. Sodoende is 'n skaakmatposisie in dié debat bereik. Daarbenewens word Paulus se doring in die vlees (2 Kor. 12) selde, indien ooit, in hierdie debat ter sprake gebing. Het hierdie onderskeie Skrifgedeeltes iets vir die verklaring van die ander te sê? Die teologiese implikasies van die argumente wat in hierdie debat aangevoer word, word verder nie altyd tot hul uiterste konsekwensies deurdink nie. Impulsiewe teologisering wat hieruit voortvloei, dra ook nie tot vordering in die diskoers by nie. Die artikel poog om op 'n verantwoordelike wyse momentum aan die diskoers te gee.

Hierdie diskoers is egter meer as van akademiese belang. Vir die pastorale bediening is dit belangrik om te weet of Christen-gelowiges wél gebind kan word. Immers, wie met 'n lidmaat pastoraal omgaan asof hy demonies gebind is terwyl dit nie so is nie, begaan ' $\mathrm{n}$ groot fout. Maar ook omgekeerd: Wie 
aanvaar dat 'n gelowige nie gebind kan wees nie terwyl dit wél moontlik mag wees, faal in sy pastorale hulpverlening. Aangesien ' $n$ diakoniologiese benadering met die Skrif wil begin, is die eksegetiese debat oor Lukas 13:10-17 en 2 Korintiërs 12:1-10 wesenlik belangrik.

\section{Doelwit van die artikel}

Hierdie artikel wil diepgang in die debat bring deur die teologiese implikasies van argumente rondom die betrokke Skrifgedeeltes te evalueer en die diskoers in 'n wyer dogmatiese en eksegetiese konteks te plaas. Hierdie artikel wil dus 'n bydrae lewer om die gestagneerde debat op dreef te kry.

\section{Hipoteses}

Die navorsing waarop hierdie artikel gebaseer is, gaan uit van die hipotese dat epistemologiese vertrekpunte tot nog toe verhinder het dat die eksegetiese ondersoek objektief en met 'n onbevange gemoed kon plaasvind. Hierdie navorsingsvermoede word gestimuleer deur opsigtelike pogings wat vanuit 'n bepaalde epistemologie aangewend word om tot 'n vooropgestelde gevolgtrekking te kan kom of die teen-argumente te neutraliseer. In die verslag van AKLAS aan die Algemene Sinode (1986:145) van die Nederduitse Gereformeerde Kerk word byvoorbeeld gesê dat die idee van demoniese besetenheid veral in charismatiese geledere voorkom "alhoewel hierdie klanke tans ook in geledere van die [g]ereformeerde [k]erke gehoor word". Hierdeur word die indruk geskep dat die gedagte van demoniese besetenheid vreemd aan die gereformeerde leer is. Só 'n benadering versterk die vermoede dat epistemologiese uitgangspunte die beoordeling van 'n teks kan beïnvloed.

\section{Metodologie}

- Gevolgtrekkings en uitsprake wat in die debat oor Lukas 13 gemaak is, word krities in die lig van Skrifgegewens en relevante uitgangspunte van die gereformeerde dogmatiek geëvalueer. Dit verteenwoordig die induktiewe aspek van die navorsing.

- In 'n deduktiewe oefening word die hulp van betroubare kommentare ingeroep om eksegetiese helderheid oor die hantering van die betrokke teksgedeeltes te kry.

- Deduktiewe en induktiewe metodes word onderskei maar nie konsekwent in afdelings geskei nie. 


\section{Hermeneutiese uitgangspunt}

Een van die redes waarom sommige teoloë weier om 'n moontlike verband tussen die betrokke Skrifgedeeltes en demoniese binding te aanvaar, moet uit die hermeneutiese vertrekpunt verklaar word. Die hermeneutiese vertrekpunt waarmee gewerk word, is dat die skopus van 'n betrokke Skrifgedeelte of perikoop die interpretasie daarvan bepaal. Vanuit hierdie beginsel word dan geredeneer dat dit in Lukas 13 of 2 Korintiërs 12 nie oor demoniese binding gaan nie. In Lukas 13 gaan dit volgens hierdie argument oor die triomf van Christus oor die Bose terwyl dit in 2 Korintiërs 12 oor die gevaar van geestelike roem gaan. Wat laasgenoemde betref, is die doring in die vlees aan Paulus gegee om geestelike hoogmoed by hom te voorkom. Wat die doring in die vlees was, is nie ter sake nie. Klem word op die opmerking van sommige kommentare gelê dat die doring in die vlees "n gawe van God" is (bv. Grosheide, 1959:347). In die lig van hierdie siening het hierdie Skrifgedeeltes dan niks met demoniese binding te doen nie.

Dit is natuurlik wáár dat die skopus die verklaring van 'n bepaalde Skrifgedeelte bepaal. Wat egter in hierdie argument buite rekening gelaat word, is dat gegewens wat in die betrokke perikoop voorkom en dalk nie direk met die skopus in verband staan nie, ewe belangrik en trouens ook deel van die Godsopenbaring is. Ons sou hier van 'n newe-skopus kon praat. Immers, as dit nét om die hoofskopus gaan en as uit "terloopse" of bykomstige gegewens geen afleidings gemaak mag word nie, sou die leer van die Drie-eenheid van God ook nie in die Skrif gefundeer kon word nie. Die gedeeltes in die Bybe! waaruit afleidings oor die Drie-eenheid gemaak word, se skopus is tog nooit die Drieeenheid nie! Trouens, daar is nêrens in die Skrif 'n perikoop waarvan die skopus uitdruklik die leer van die Drie-eenheid ekspliseer nie. Tog het dit nog nooit die kerk verhinder om met oortuiging die leer van die Drie-eenheid te glo en te verkondig nie. Waarom nie? Omdat uitsprake wat in Skrifgedeeltes voorkom, nie misgekyk kan word nie al hou dit nie direk met die skopus van daardie Skrifgedeeltes verband nie.

Hermeneutiese beginsels moet tog dienstig aan die Skrifverstaan wees en nie die Skrifbestudeerder tot 'n dienskneg van die hermeneutiese beginsels maak nie. Heyns en Jonker (1977:283-284) waarsku juis teen twee gevare wat die hermeneutiese proses kan bedreig. Enersyds moet die hermeneutiek altyd aan die beginsel getrou bly dat die Skrif sy eie verklaarder is (Sacra Scriptura sui ipsius interpres). Andersyds moet daar gewaak word teen 'n epistemologiese beïnvloeding wat die hermeneutiek nie langer slegs met die reëls vir die verstaan van die Skrif besig laat wees nie, maar ook met die verstaansproses self. Albei hierdie waarskuwings is in die navorsing oor hierdie onderwerp van belang. 
Die hermeneutiese uitgangspunt dat ons in Skrifuitsprake oor die duiwel en demoniese binding of besetenheid met 'n beperkte wêreldbeeld te doen het en dat dergelike toestande vandag met bekende siektes in verband gebring kan word, kan nie in 'n artikel met 'n beperkte omvang volledig aandag geniet nie. Kortweg kan gestel word dat só 'n hermeneutiese vertrekpunt nie logies met Skrifgedeeltes oor die onderwerp versoenbaar is nie. Hoe kan die varke se besetenheid in Markus 5:1-20 met só 'n hermeneutiek verklaar word? Hoe kan dit vanuit hierdie hermeneutiese vertrekpunt logies verstaan word dat die dissipels in Markus 9:28-29 kla dat hulle nie in staat was om die duiwels uit te dryf nie en dat Jesus hulle antwoord: "Hierdie soort goed kan met niks anders as met gebed uitgedrywe word nie." Nog duideliker blyk dit uit Matteus 12:4345 dat Jesus nie slegs van siektetoestande praat nie en ook nie maar net by 'n bepaalde wêreldbeeld aansluit nie. Immers, waarom sou Jesus sy dissipels só leer en waarom sou Jesus die bose geeste betig het (bv. Matt. 17:18) as daar nie so iets soos demone of besetenheid is nie? In Markus 1:21-31 word 'n besetene se gedrag beskryf voordat Jesus die bose gees bestraf en hy stuiptrekkings kry. In hierdie geval gaan dit dus nie slegs oor simptome wat met bepaalde hedendaagse siektes in verband gebring kan word nie. Nog Skrifgedeeltes kan aangewend word om die wêreldbeeld-hipotese te toets en af te wys. Genoeg redes is egter verskaf waarom hierdie hermeneutiese uitgangspunt nie aanvaarbaar is nie.

\section{6. 'n Teologiese bespreking van Lukas 13:10-17}

'n Bespreking van Lukas 13:10-17 wat aan die vereiste van deeglikheid wil voldoen, moet veral op die volgende aspekte in die Skrifgedeelte konsentreer:

\subsection{Die oorsprong van die kwaal}

In die betrokke Skrifgedeelte verkry die oorsprong van die vrou se kwaal prominensie deur die verduideliking wat die Here Jesus in vers 16 gee. Vir die eksegetiese verstaan van die teks moet vers 15 saam met vers 16 gelees word. Die hoof van die sinagoge was verontwaardig oor die vrou se genesing (v. 14a). Jesus wys egter op hulle dubbele maatstawwe: hulle het nie beswaar daarteen dat 'n bees of donkie op die Sabbat losgemaak word om die dier water te laat drink nie. Wanneer die vrou egter van die Satan se binding op die Sabbat losgemaak word, is hulle erg beswaard. Danker (1988:262) beskryf die binding soos volg: "For eighteen years she has been, one might say, in Satan's stall ..." Juis hierdie inligting stel die triomf van Christus oor die Bose in die regte konteks. Daarsonder sou dit 'n "gewone" genesing van 'n sieke gewees het. Die oorsprong van die vrou se probleem het dus alles te make met die skopus van die Skrifgedeelte (die triomf van Christus se oorwinning). In die lig van die voorafgaande is dit onverklaarbaar waarom AKLAS (1986:145) beweer dat dit onskriftuurlik is om af te lei dat die vrou in Lukas 13:10-17 okkulties gebind 
was, aangesien die oorsaak van die vrou se gebondenheid na hulle mening nie bekend is nie. Die beredenering in die verslag is egter onduidelik en verwarrend aangesien Lukas 13:16 uitdruklik sê dat dit die Satan is wat haar so lank gebonde gehou het. Wie dit ontken, gaan aan die eksegetiese betekenis van die Skrifgedeelte verby.

\subsection{Die aard van die kwaal}

Die aard van die kwaal word in vers 11 as 'n ingrypende liggaamlike verswakking geïdentifiseer. Dit het daartoe gelei dat haar hele liggaam kromgetrek was sodat sy nie regop kon kom nie. Hoewel daar met vandag se mediese kennis talle diagnostiese moontlikhede vir só 'n simptomatologie is, word die toestand in die eksegetiese konteks met demoniese aktiwiteit in verband gebring en as 'n binding getipeer. Klaarblyklik wil AKLAS (1986:145) 'n binding slegs tot die geestelike sfeer (pneuma astheneias) beperk. Omdat dit hier om 'n liggaamlike gebrek gaan, word gekonkludeer dat dit nie as 'n binding getipeer kan word nie. Só 'n beredenering verraai 'n epistemologiese prejudisering wat opsigtelik die voorhande teksgegewens manipuleer. Gous (1983:40) verklaar kategories dat daar geen rede is waarom die vrou se gebrek nie as ' $n$ binding bestempel kan word nie. Daaruit kan afgelei word dat 'n binding op 'n liggaamlike gebondenheid (aantasting) vanuit 'n demoniese oorsprong kan dui, hoewel met Thurneysen (1963), Smit (1992a:6) en andere ook saamgestem moet word dat dit ' $n$ geestelike gebondenheid kan wees. Die afleiding dat 'n binding ook (soos met die vrou van Luk. 13) op 'n liggaamlike gebondenheid kan dui, is relevant vir die eksegetiese bespreking van 2 Korintiërs 12:1-10. Daarop word dus later teruggekom.

\subsection{Die identiteit van die vrou}

Die afleiding word uit Lukas 13:10-17 gemaak dat gelowiges ook gebind kan word omdat vers 16 uitdruklik vermeld dat die vrou 'n kind van Abraham was. Die argumente teen hierdie afleiding loop samevattend soos volg: Uit die vermelding dat die vrou 'n kind van Abraham was, kan niks meer afgelei word as dat sy 'n Israeliet was nie. Dit sê egter niks oor haar geloofsposisie nie. Die volgende kritiese opmerkings laat blyk egter dat die saak nie so eenvoudig afgemaak kan word nie. 'n Hele aantal teologiese vertrekpunte is op die spel:

Jesus wil klaarblyklik steun aan sy woorde verleen deur na die vrou se verbondsverbintenis te verwys. Omdat sy aan die verbondsvolk van God behoort, behoort die sinagoge meer waarde aan haar toe te ken as aan 'n dier wat op die Sabbat losgemaak mag word om te drink (Wiefel, 1988:256). Verskeie kommentatore (byvoorbeeld Fitzmyer, 1985:1011) interpreteer die verwysing as a minori ad maius: as dit vir 'n dier geld, soveel te meer vir 'n mens, soveel te meer vir 'n dogter van Abraham. Marshall (1978:559) gee selfs 
ander Skrifverwysings om te bevestig dat die vrou as deel van die Godsvolk beskou moet word:

For Jesus, although she is a woman (and therefore regarded as less important than men in Jewish thought), she is nevertheless a descendant of Abraham (cf. 1:55), and like Zacchaeus (19:9) a member of God's people (Acts 13:26). It may be that the Jews denied her this position, since her illness might have been regarded as a sign of sinfulness (cf. 13:2), but Jesus affirms it (kursivering - J.v.R.).

Teen hierdie agtergrond is Rengstorf (1978:171) se opmerking betekenisvol dat Jesus se verwysing na die vrou se verbintenis met Abraham in 'n patriargale bedeling 'n ongewone stap was waarmee $\mathrm{Hy}$ 'n belangrike aksent op die diskoers wou plaas. Daaruit moet afgelei word dat die uitdrukking nie bloot as 'n genealogiese aanwysing kan dien nie. Fitzmyer (1985:1013) verklaar die uitdrukking eweneens as 'n aanduiding dat die vrou deel van die uitverkore volk was. Leaney (1976:207) en Schweizer (1984:222) bring die vrou se kindskap van Abraham in verband met Jesus se woorde aangaande Saggeus (Luk. 19:9), terwyl Schweizer op die aangehaalde plek ook nog verklaar dat Jesus met die uitdrukking en die verwysing na die binding van demoniese oorsprong sy genesingsdaad op die Sabbat binne konteks plaas ("something more than rational liberalism").

Leaney (1976:241) beskryf die uitdrukking "n kind van Abraham" as "This notion of salvation ..." (vergelyk ook Danker, 1988:262). Volgens Nielsen (1983:18-19) dui die uitdrukking op eienaarskap. Soos die eienaar sy dier mag losmaak om te drink, soveel te meer mag God sy eiendom op sy dag van die binding van die duiwel losmaak. Ook Van Bruggen (1993:268-269) verklaar op dergelike wyse die uitdrukking vanuit die eienaarskap van God. Die uitdrukking het syns insiens alleen sin as Jesus met dié uitdrukking sy eienaarskap oor die vrou veronderstel. Vanuit hierdie vertrekpunt word die vrou as eiendom van God bestempel. Ernst (1977:423) lê 'n verband tussen die uitdrukking "dogter van Abraham" en die Dekaloog. As dogter van Abraham het sy deel aan die verbondswet en behoort die vierde gebod dus tot haar heil te dien en nie tot belemmering op die weg na genesing nie. Grundmann (1981:280) se verklaring kom hoofsaaklik hiermee ooreen terwyl Rengstorf (1978:171) ook nog die reg op die liefdesgebod aan die "dogter van Abraham" verbind.

Noemenswaardig in hierdie verband en ter ondersteuning van die hipotese van hierdie artikel is die verduideliking wat Gous (1983:40-42) vir die geloofsposisie van die vrou gee. Hoewel hy met Skrifverwysings wat met verlossing in verband staan, kategories beweer dat die uitdrukking "dogter van Abraham" nie net 'n spreekwyse is nie, kom hy tog tot die gevolgtrekking dat 
die vrou ' $n$ verbondskind maar nie 'n verloste was nie. Hieruit lei hy af dat ' $n$ verbondskind wel gebind kan wees maar nie 'n gelowige (Christen) nie. Die dialektiek en vreemde verbondsbeskouing is opsigtelik. Só 'n teologiese onderbou staan op losse skroewe aangesien dit nie moeilik is om aan te toon dat dit tot allerlei onbeantwoorde vrae en/of onbevredigende oplossings lei nie.

Die teologiese vraag moet immers gevra word wat die geloofsposisie van iemand in die Ou Testament was wat hom/haar met die verbondsvolk- en beloftes vereenselwig het. Volgens Bavinck (1928:531) onderskei die verbond die religie van die Bybel van enige ander religie. Die verbondsreligie is egte religie. Dit is die aanduiding dat God by die nederiges kom woon. Die gerigtheid van hierdie verbondsverwagting tipeer die waarheid en egtheid van die religie:

Het vrije, door God in zijne gunst gesloten verbond werd meer en meer de vastigheid van lsraëls geloof en de grond zijner hope voor de tockomst. Jes. 54:10. Van al de verwachtingen, die Israël koesterde, bleek meer en meer, dat zij uitsluitend rustten in het verbond. dat God in zijne genade met zijn volk had opgericht; dat verbond alleen verzekerde aan Israël zijn voortbestaan. de verschijning van den Messias en al de zegeningen van het toekomstige Godsrijk (Bavinck, 1929:180).

Uit hierdie lywige aanhaling blyk duidelik watter impak die genadeverbond verkry het. Aan hierdie verbond, met sy Messiaanse betekenislading, het die vrou van Lukas 13:10-17 deel gehad.

Teen hierdie teologiese agtergrond is die eksegetiese verklaring deur die gereformeerde eksegeet, S. Greijdanus, betekenisvol en ondubbelsinnig. Greijdanus (s.j.:16) stel dit uitdruklik dat die uitdrukking "dogter van Abraham" hierdie vrou as 'n gelowige en verloste vrou tipeer. Omdat sy verklaring so eksplisiet is, is dit beter om Greijdanus sélf aan die woord te stel:

Mocht de satan haar langer overheersen? Is er wel ontferming bij u over uw beest, maar geen erbarming over deze lijdende vrouw, die niet alleen ook uit Abraham gesproten is, evenals gij, uw medemens niet slechts, maar ook uw mede-Israëliete, ja, die bovendien een geestelijke dochter van Abraham is? Haar geloof in den Heere had zij duidelijk geopenbaard ook in haar danken en prijzen van God, vs. 13. Bovendien kende de Here ook haar hart van tevoren wel, vgl. Joh. 2:24-25.

Die laaste opmerking van Greijdanus is betekenisvol. Dit is inderdaad onwaarskynlik dat Jesus na die vrou se verbondsverbintenis met Abraham sou verwys as Hy (die kenner van mense se harte) geweet het dat sy geen erg aan die verbond en die beloftes gehad het nie. Wie beter as Hy sou weet dat nie almal Israel is wat uit Israel is nie (Rom. 9:6)? Calvyn (1964b:538) verduidelik die 
betekenis van hierdie uitdrukking in Romeine 9. Hy wys daarop dat Paulus daarmee wil aantoon dat die Jode geen rede tot roem op grond van hulle afkoms het nie, tensy hulle die verbondswet en woord eerbiedig. Dat Jesus dus tog na die vrou as 'n dogter van Abraham verwys, bevestig haar geloofsintegriteit en dui aan dat dit as ' $n$ betekenisvolle uitdrukking verstaan moet word. Daar is op grond van die voorafgaande dus geen eksegetiese getuienis om te aanvaar dat die vrou van Lukas 13:10-17 nie as 'n gelowige vrou getipeer kan word nie. As die Skrif sy eie verklaarder is, kan hierdie feit nie misken word nie.

\section{7. 'n Teologiese bespreking van 2 Korintiërs 12}

In die verlede is die debat oor 2 Korintiërs 12 oorheers deur 'n bespreking van die "doring in die vlees" (v. 7). Dit is begryplik dat eksegete probeer vasstel het wat die doring in Paulus se vlees was, hoewel Grosheide (1959:347) waarsku dat die uitdrukking "doring in die vlees" te vaag is om iets konkreets daaruit af te lei. Daarbenewens loop die eksegese 'n gevaar om in eendimensionaliteit te verval wanneer die aandag so eensydig op die uitleg van die "doring in die vlees" val. Ten einde hierdie gevaar te vermy, word die betrokke perikoop onder drie afdelings behandel.

\subsection{Die rede vir die doring in die vlees}

Die eksegetiese verstaan van die perikoop sentreer hoofsaaklik in die "daarom, sodat" (dió hina) van vers 7. Grosheide (1959:346-347) wys daarop dat die konstruksie nie op die eerste gedeelte van die perikoop as 'n redegewing vir die roem in swakheid dui nie, maar as 'n konklusie daarna. Die betekenis "daarom ook" of "derhalwe" dui dus op die slotsom waartoe Paulus kom, naamlik dat die vuiste waarmee die engel van Satan hom slaan, hom van geestelike hoogmoed weerhou. Op die aangehaalde plek wys Grosheide daarop dat die uitdrukking (hina mé huperairomai) aan die einde herhaal word om die belang daarvan te beklemtoon. So word dit dan onmoontlik om die uitdrukking "'n engel van die Satan om my met vuiste te slaan" as 'n terloopse opmerking te beskou wat nie met die skopus van die perikoop te doen het nie en wat dus ook nie aandag verdien nie.

\subsection{Die oorsprong van die doring in die vlees}

In sy geheel gesien, het die doring in die vlees 'n tweeledige oorsprong. Enersyds word dit toegeskryf aan 'n engel van die Satan wat Paulus met vuiste slaan, maar andersyds sê Paulus ook dat dit hom (van die Here) gegee is. Hoe kan die doring in die vlees deur God gegee wees maar tog van die duiwel kom? Calvyn (1964a:198-205) se duidelike verklaring in dié verband is hier ter sake. Hy gee oorvloedige Skrifgetuienis van die feit dat God die Satan nie slegs toelaat om mense se lewens te beïnvloed nie, maar dat die Here die Bose selfs 
in iemand se lewe kan stuur. In 'n lesenswaardige uiteensetting wat dogmatiese diepgang bereik, wys Calvyn daarop dat dit dikwels in Israel se geskiedenis sowel as in individue se lewe gebeur het. God het byvoorbeeld 'n bose gees na Saul gestuur (1 Sam. 16:14). In hierdie handeling van God is daar geen innerlike teenstrydigheid nie. In dieselfde trant konkludeer Ouweneel (1978:123) dat Satan onder toelating van die Here mense verblind, hulle harte verhard en mense verhinder om te glo. Só word demone dan agente van God om sy volmaakte wil in werking te stel.

Dit hoef dus hoegenaamd nie vreemd aan te doen dat God sy doel met Paulus bereik het deur ' $n$ engel van Satan te stuur om hom met vuiste te slaan nie. Grosheide (1959:349) erken inderdaad die moontlikheid dat Paulus besef het dat die engel van Satan deur die Here toegelaat is om hom "met vuiste te slaan". En is dit nie presies wat God in Job se lewe gedoen het nie? Wilson (1979:159), Groenewald (1967:166), Hughes (1962:447), Barnett (1988:178) en Carson (1984:144) verwys na die geval van Job as 'n hulpmiddel om te verstaan wat met Paulus gebeur het. Die engel van Satan word toegelaat (gestuur) om Paulus met vuiste te slaan maar Satan word ook gefrustreer deur die feit dat God hierdie aanslae in diens neem om sy doel met Paulus te bereik.

Daarbenewens word die aandag ook op die werkwoord in die uitdrukking édóthe moi skólops te sarkí van vers 7 gevestig. Kan ons uit die werkwoord édóthe aflei dat Paulus die doring in die vlees, die engel van Satan wat met vuiste slaan, as 'n gawe beskou het? Moet die édóthe met die dió eúdokó van vers 10 in verband gebring word en moet ons daaruit aflei dat Paulus dankbaar oor die doring in die vlees, die engel van die Satan was? Die relevansie van hierdie inligting sal in 'n volgende afdeling duidelik word. Intussen word daarop gewys dat die eudoko op die swakheid dui wat Paulus as gevolg van die duiwel se vuiste aangedoen is en nie primêr op die engel van die Satan se vuiste as sodanig nie. Grosheide (1959: 351) meen dat dit op Paulus se liggaamlike toestand dui. Dit wil dus voorkom of Paulus dankbaar is dat hy verswak is en daardeur verhinder word om te roem en in geestelike hoogmoed te verval. Dit is egter moeilik om uit die semantiek af te lei dat Paulus oor die vuiste van die engel van Satan dankbaar was. Daar moet onthou word dat Paulus drie keer (volgens Grosheide, 1959:348 dui dit op drie tydperke in sy lewe) intensief gebid het dat die Here die engel van die Satan wat hom met vuiste slaan, moes wegneem. Aanvanklik het Paulus die doring in die vlees dus nie as gawe beskou nie. Toe dit vir hom duidelik word dat die Here 'n doel daarmee het, naamlik om hom nederig te hou en teen geestelike hoogmoed te bewaar, het hy dit as noodsaaklike gegewenheid van God aanvaar. Daarbenewens gee die teks geen aanduiding dat Paulus die Here vir die doring in die vlees gedank het nie. Daar staan dat hy bly is oor swakhede, beledigings, ontberings, vervolging en moeilikhede (v. 10) omdat dit hom swak hou en hom verhinder om op homself 
te roem. In dieselfde sin wat Paulus sy ontberinge aanvaar het, het hy geleer dat die doring in die vlees nodig is om hom nederig te hou (Hughes, 1962:447). In die lig van dié gegewens sou 'n mens dus liewer nie soos Grosheide (1959:346347) die édóthe as 'n gawe tipeer nie, aangesien die term gewoonlik 'n ander betekenislading het (bv. 1 Kor. 12 en 14; Ef. 4:11). Daar is geen eksegetiese aanwysings om van édóthe na charisma(ta) te konkludeer nie.

\subsection{Die aard van die doring in die vlees}

Dit is onnodig om hier nogeens in die spekulasie oor die aard van die doring in die vlees te verval. Dit is egter genoeg om daarop te let dat die doring in die vlees nie maar net 'n swakheid, probleem of teenstand kon wees nie, maar pertinent geïdentifiseer word as 'n engel van die Satan om hom met vuiste te slaan. Die uitdrukking is so eksplisiet (Loubser, 1981:259) dat die betekenis daarvan op sigwaarde geneem moet word. Dit is dus nie 'n uitdrukking wat bloot na 'n buitengewone versoeking verwys nie. Dit kan ook nie, soos Tasker (1981: 177), Loubser (1981:266-268) en Louw en Stander (1981:271-272) beweer, bloot op die teenspoed dui wat Paulus gehad het of op die teenstand wat hy van die Satan of die Jode ondervind het nie. Hoewel Louw en Stander (1981:271-272) daarop wys dat hierdie verklaring deur die meeste kerkvaders ondersteun is, is die argumente wat deur Loubser (1981) en Louw en Stander (1981) aangevoer word, om die volgende redes nie deurslaggewend nie:

- Teenoor die argument dat die meeste kerkvaders die doring op teenstand laat dui, kan aangevoer word dat Loubser (1981:262) sélf verwys na "'n magdom geleerdes" wat die doring as 'n liggaamlike aantasting beskou, terwyl Louw en Stander (1981:272) skryf: "Dit is opvallend hoe sterk die oortuiging is dat die 'doring in die vlees' die een of ander siekte moet wees".

- Loubser (1981:265) konkludeer dat daar geen rede is waarom ángelos op 'n siekte of kwaal moet dui nie, maar gee dan onmiddellik toe dat dit 'n denkmoontlikheid is.

- Loubser (1981:263-265) bou sy argumentasie hoofsaaklik op die vergelyking van soortgelyke frases in ander Skrifgedeeltes, maar Louw en Stander (1981:269-270) waarsku juis dat parallelle nie waterdigte eksegetiese konklusies waarborg nie.

- Die semantiese betekenis en eksegetiese konteks dui op iets persoonliks wat Paulus as ' $n$ belemmering van sy sending ervaar. Juis daarom kan die doring in die vlees nie op die teenstand van vyande dui nie, omdat ál die apostels van die Here sowel as die Christene van die Nuwe-Testamentiese kerk hierdie vervolging en teenstand ervaar het. Indien die doring in die vlees dáárop sou dui, sou dit geen uitsondering wees om só 'n doring in die vlees 
te hê nie. Dan sou al die Christene in die Nuwe Testament só 'n doring in die vlees (engel van die Satan) gehad het. Carson (1984:144) gebruik juis die teenstand wat Paulus ondervind het as vertrekpunt om soos volg te redeneer: As Paulus bereid was om soveel ter wille van die evangelie te ontbeer maar dan tog 'n probleem met die doring in die vlees ervaar het en dit graag weggeneem wou hê, dan moes dit iets buitengewoon pynliks of/en vernederends gewees het. Hier word die doring in die vlees en die teenstand as twee afsonderlike werklikhede in Paulus se lewe gestel.

- Dit sou vreemd wees dat Paulus so intens gebid het dat die doring weggeneem moet word as dit op teenstand sou dui, aangesien Christus juis die apostolaat aan vervolging en lyding verbind het (Matt. 10:23; Joh. 15:20, ens.), terwyl lyding en teenstand van die begin af deel van Paulus se roeping was (Hand. 9:16; vergelyk in hierdie verband ook uitsprake in Rom. $8: 35 ; 2$ Kor. $12: 10$ en 2 Tim. 3:11-12). Teen hierdie agtergrond is dit onwaarskynlik dat Paulus dus sou bid dat die teenstand moes weggaan. Hy het tog geweet dat dit onmoontlik sou wees om sonder teenstand die evangelie te verkondig. Dit is dus hoogs onwaarskynlik dat die doring in die vlees op teenstand sou dui.

- Loubser (1981:265) beweer : "Verder moet diegene wat met alle geweld skolops as siekte wil verklaar, die vermelding van die Satansengel verduidelik met die geforseerde beskouing dat liggaamlike gebrek en siekte demoniesbelade is ...". Die moontlikheid dat liggaamlike aantasting 'n demoniese oorsprong kan hê, word egter uitdruklik deur Lukas 13 voorgehou. Die verklaringsmoontlikheid is dus hoegenaamd nie geforseerd nie. Daarbenewens hoef 'n liggaamlike aantasting nie 'n siekte te wees nie, terwyl dit ook nie beweer word dat alle siekte altyd deur demoniese invloed bewerk word nie.

Die "daarom" in vers 10 noodsaak nie die verklaring dat die doring in die vlees en die teenstand een en dieselfde is nie. Dit wil eerder voorkom of Paulus met 'n konstellasie-argument besig is. Ten einde te verhinder dat hy op sy ervaring (vers 1-4) sou roem, is die doring in die vlees gegee. Daarom is hy oor vervolging ensomeer dankbaar omdat dit ook dieselfde uitwerking het: dit hou hom nederig en versterk dus die werking van die doring in die vlees (sien ook weer voorafgaande opmerking in hierdie verband by 7.1). Ter versterking van die konstellasie-argument val dit verder ook op dat die swakheid waaroor Paulus bly is (vers 9), onmiddellik ná die doring in die vlees gemeld word en direk daarmee in verband gebring word. Die swakheid word in vers 10 eerste as 'n afsonderlike saak genoem (in opvolging van die argument in vers 9) en eers daarna word na beledigings, ontberings, vervolgings en moeilikhede verwys. Die swakheid wat deur die doring in die vlees veroorsaak word, is dus iets 
anders as die vervolging en ontberings, maar dit het dieselfde uitwerking: om Paulus te verhinder om te roem.

Dit is korrek dat ons nie weet wat Paulus se doring in die vlees was nie (vir 'n interessante diskussie hieroor, vergelyk Minn, 1972:23-30; Hughes 1962:442448). Vir die verstaan van die Skrifgedeelte is dit ook nie nodig om presies te weet nie. Die eksegetiese kommentaar wat in die afgelope dekades hieroor uitgespreek is, dui in elk geval oorweldigend daarop dat dit een of ander kwelling van die liggaam was (bv. Wilson, 1979; Kent, 1982 en Groenewald, 1967). Wat dit ook al was, dit was 'n kroniese probleem wat hom liggaamlik verswak en selfs by tye verhinder het om met sy werk voort te gaan. Hierdie doring het sy bediening aan bande gelê en daarom het hy die Here gevra om dit weg te neem (Kent, 1982:184).

Grosheide (1959:348) se kommentaar verdien egter meer aandag. Hy kies vir die moontlikheid dat die doring in die vlees epileptiese aanvalle was en motiveer sy spekulasie met behulp van die aanhaling van Galasiërs 4:14. Uit dié gegewens lei hy af "dat Paulus iets ondervond, dat hem smadelijk, verachtelijk maakte in de ogen der mensen, waardoor zij er niet toe kwamen hem te prijzen en aldus Paulus' trots te prikkelen". Indien hierdie verklaring as moontlikheid oorweeg word, open dit weer die hele diskoers oor demoniese werking en epilepsie. Immers, dan het ons 'n manifestasie van epilepsie wat deur 'n engel van die Satan bewerk is. Dan sou die charismatiese epistemologie (dat epilepsie op okkultiese binding mag dui) nie sonder meer verwerp kon word nie. Daar is egter twee oorwegings wat hierdie vertrekpunt strem. Enersyds erken Grosheide dat enige verklaringsmoontlikheid slegs spekulasie kan wees. Daar kan dus nie met sekerheid beweer word dat dit wél epilepsie was nie. Maar andersyds moet ook onthou word dat medikasie vandag die simptomatologie van epilepsie effektief kan beheer. Indien ons aanvaar dat epilepsie sonder meer ' $n$ okkultiese binding is, het dit die implikasie dat demoniese magte met medikasie beheer kan word. Eksegetiese en praktiese oorwegings mak dit dus onwenslik om met sekerheid uit die doring in die vlees af te lei dat epileptiese aanvalle 'n binding van Satan is.

Op hierdie punt ontstaan die verdere vraag of ons nie die doring in die vlees as 'n "binding" van Satan (soos by Lukas 13:10-17) kan tipeer nie? Paulus is deur 'n engel van die Satan aangeval (met vuiste geslaan) en die konsekwensie van hierdie aanval was dat hy 'n liggaamlike aantasting ondervind het. Volgens die algemene beskouing (byvoorbeeld Gous, 1983:40 en Ouweneel, 1978:349) word 'n binding inderdaad deur hierdie twee kenmerke geidentifiseer: 'n geestelike of liggaamlike aantasting met 'n demoniese oorsprong. Weliswaar is daar geen aanduiding dat Paulus met okkultisme deurmekaar was nie, maar Gous (1983:43) waarsku: "Die binding deur Satan is veel meer gesofistikeerd en verfynd as om dit bloot toe te skrywe aan okkultiese kontakte." As 
2 Korintiërs 12:1-10 met Lukas 13:10-17 in verband gebring word en as Gous se opmerking ernstig geneem word, sou dit vergesog wees om van Paulus se doring in die vlees as 'n "binding" te praat? Iemand soos Berkouwer (1958:103) verklaar juis die doring in die vlees van 2 Korintiërs 12 vanuit die binding van die vrou in Lukas 13:10-17. Hy tipeer die vrou in Lukas 13 se toestand as 'n binding (kursief deur Berkouwer) en beskryf dit as 'n manifestasie van die mag (exousia) van die Bose tot blindheid, stomheid en selfvernietiging. Hierdie gegewens plaas Paulus se ervaring van die sataniese aanval in perspektief, aldus Berkouwer. Indien dit minstens 'n geldige oorweging is en 2 Korintiërs 12:1-10 saam met Lukas 13:10-17 gelees word (soos Berkouwer aandui), plaas dit die hele diskoers oor die binding van gelowiges op die tafel.

\subsection{Pastorale merkers}

Die eksegetiese gegewens uit Lukas 13:10-17 en 2 Korintiërs 12:1-10 is vir die diskoers oor okkultiese manifestasies uiters relevant. Veral drie sake kom na vore:

- Die debat oor die vraag of gelowiges gebind kan word, is nog lank nie afgehandel nie. In teenstelling met die Sinode van die Nederduitse Gereformeerde Kerk van Suid-Transvaal (1993), wat dit as 'n dwaling beskou indien iemand beweer dat 'n Christen gebind kan word, het die Sinode van die Nederduitse Gereformeerde Kerk in die Vrystaat (1995) hieroor verdere ondersoek gevra. Die moontlikheid word dus deur laasgenoemde nie algeheel verwerp nie, terwyl gesaghebbendes soos Ouweneel (1978:333-335, 350), Parker (1989:30-31) en Huisamen (1990:54) oortuig is dat Christene wél gebind kan word. Koch (1962:177-178), na wie die behoudende teoloog F.J.M. Potgieter (1974:10) as 'n gesaghebbende verwys, vertel die aangrypende verhaal van Koimbo, 'n Christen in die sendingveld van New Guinea, wat as Christen deur 'n demoniese binding blind geword het. Hierdie mededeling skep die indruk van outentisiteit en bevestig dat Christene wél gebind kan word maar ook deur die oorwinning van Jesus Christus bevry kan word.

Indien Lukas 13:10-17 en 2 Korintiêrs 12:1-10 met 'n oop gemoed ontleed word, kan die aanduidings dat gelowiges wél gebind kan word, nie sonder meer verwerp word nie. As volgens Zerfass se model vir basis-teoretiese vorming (soos aangehaal deur Heyns \& Pieterse, 1990:33-37) na die eksegetiese merkers, die teologiese diskoers van teoloë soos Ouweneel en Huisamen en die getuienis uit die praktyk gekyk word, kan moeilik tot 'n ander slotsom gekom word. Wat laasgenoemde betref, is meer empiriese navorsing egter nodig om die wetenskaplike bewysvoering in dié verband omvattend te substansieer en te spesifiseer. 
'n Suiwer empiriese benadering stuit egter juis teen die probleem dat die aanwesigheid en integriteit van geloof nie empiries bepaalbaar is nie (Louw, 1993b:207-209). Dei intimis non iudicat ecclesia (oor die innerlike van iemand kan die kerk hom nie uitspreek nie). Empiriese navorsing moet dus rekening hou met die komplikasies en implikasies van die vraag: "Is of was die persoon met 'n binding werklik 'n gelowige?" 'n Diakoniologiese benadering wil op 'n gebalanseerde wyse Skrif en belydenis aan die empiriese navorsing vooraf laat gaan. Aan hierdie holistiese benadering oor die moontlike binding van ' $n$ gelowige ontbreek dit tans nog in die vakliteratuur.

- Die oorsprong van Paulus se doring in die vlees ('n engel van Satan wat hom met vuiste slaan) moet beskou word as ' $n$ belangrike aanduiding vir die pastorale versorging van mense met okkultiese kwelling, of ons dit as 'n "binding" wil tipeer of nie. In die pastorale verwysingsraamwerk sou na aanleiding van Paulus se geval die moontlikheid minstens oorweeg en ondersoek moet word dat nie alle mense noodwendig van bindinge of demoniese aantastings bevry sal kan word nie. Dit mag immers wees dat God daarmee, soos met Paulus se geval, 'n doel het. Die "sukses" van die bediening moet dus nie sonder meer in die bevryding van bindinge of die verdwyning van die simptomatologie gesoek word nie, maar in die vrug van die geloof in Jesus Christus as Here en Verlosser. Die obsessie onderliggend aan die charismatiese paradigma om in elke onderhawige geval elke denkbare verskynsel as ' $n$ besetting of binding te sien en dit met eksorsisme te verdryf, staan in die lig hiervan uiters bedenklik, veral as die simptomatologie nie verdwyn nie en die persoon dan van ongeloof of reddeloosheid beskuldig of verdink word. Indien dit duidelik word dat die sogenaamde simptomatologie na langdurige gebed nie verdwyn nie, behoort die pastoraat dus op sinduiding en aanvaarding afgestem te word. Jesus se belofte in Johannes 8:32 bly ook in só 'n geval van krag: "Julle sal die waarheid ken en die waarheid sal julle vrymaak."

- Gous (1983:42-43) se uitgangspunt dat okkultiese binding nie noodwendig deur doelbewuste betrokkenheid by okkultisme veroorsaak word nie, impliseer dat nie met sekerheid afgelei kan word dat iemand noodwendig gebind is as hy/sy wél by okkultisme betrokke was nie. Die gebruik van pastores om betrokkenheid by okkultisme as 'n primêre diagnostiese kriterium te gebruik (Smit 1981:46), moet daarom afgewys word. Daarenteen geld ook die teenoorgestelde: indien iemand nooit by okkultisme betrokke was nie, sou nie daaruit afgelei kon word dat die persoon se probleem nie 'n okkultiese oorsprong het nie. Hier kom die hele aangeleentheid van diagnostiese kriteria ter sprake, 'n saak wat natuurlik nog hoegenaamd nie verklaar is nie. Die debat tussen Louw (1993a) en Theron 
(1993) en die bydraes van Rossouw (1992) en Smit (1992b) het slegs die diskoers ingelei maar die gesprek het sedertdien gestol. Navorsing in hierdie verband word in die vooruitsig gestel.

\section{Bibliografie}

AKL.AS = Die Algemene Kommissie vir Leer en Aktuele Sake

ALGEMENE SINODE VAN DIE NED. GEREF. KERK. 1986. Agenda van die Algemene Sinode van die Ned. Geref. Kerk.

BARNETT, P. 1988. The message of 2 Corinthians. Power in weakness. Leicester : InterVarsity Press.

BAVINCK, H. 1928. Gereformeerde Dogmatiek (deel 2). Kampen : Kok.

BAVINCK, H. 1929. Gereformeerde Dogmatiek (deel 3). Kampen : Kok.

BERKOUWER, G.C. 1958. Dogmatische studiën. De zonde (deel I). Kampen : Kok.

CALVIN, J. 1964a Institutes of the Christian religion (vol. 1). Translation: Henry Beveridge. Michigan : Eerdmans.

CALVIN, J. 1964b. Institutes of the Christian religion (vol. 2). Translation: Henry Beveridge. Michigan : Eerdmans.

CARSON, D.A. 1984. From triumphalism to maturity. An exposition of 2 Corinthians 1013. Grand Rapids : Baker Book House.

DANKER, F.W. 1988. Jesus and the New Age. Philadelphia : Fortress Press.

ERNST, J. 1977. Das Evangelium nach Lukas. Regensburg : Verlag Friedrich Pustet.

FITZMYER, J.A. 1985. The Gospel according to Luke. New York : Doubleday.

GOUS, A. 1983. Perspektief op Satan en sy werkinge. Joga, transendentale meditasie. karate. Pretoria : N.G. Kerkboekhandel.

GREIJDANUS. S. s.j. Het evangelie naar Lucas (deel 2). Korte verklaring der Heilige Schrift. Kampen : Kok.

GROENEWALD, E.P. 1967. Die tweede brief aan die Korintiërs. Pretoria : N.G.K.U.

GROSHEIDE, F.W. 1959. De tweede brief aan de Kerk te Korinthe. Commentaar op het Nieuwe Testament. Kampen : Kok.

GRUNDMANN. W. 1981. Das Evangelium nach Lukas. Berlin : Evangelische Verlagsanstalt.

HEYNS, J.A. \& JONKER, W.D. 1977. Op weg met die teologie. Pretoria : N.G. Kerkboekhandel.

HEYNS, L.M. \& PIETERSE, H.J.C. 1990. A primer in Practical theology. Pretoria : Gnosis.

HUGHES, P.E. 1962. Paul's second epistle to the Corinthians. London : Marshall, Morgan \& Scott.

HUISAMEN, E. 1990. Magte van die duisternis. Kaapstad : Lux Verbi.

KENT, H.A. 1982. A heart opened wide. Studies in Il Corinthians. Michigan : Baker Book House

KOCH, K. 1962. Between Christ and Satan. Grand Rapids : Kregel Publishing. 
LEANY, A.R.C. 1976. A commentary on the Gospel according to St. Luke. London : Adam \& Charles Black.

LOUBSER, J.A. 1981. Paulus se doring in die vlees: 2 Kor. 12:7. Nederduitse Gereformeerde Teologiese Tydskrif, 22(4):259-268.

LOUW, D.J. 1993a. Diagnostiese kriteria vir die evaluering van Satanisme in die pastorale bediening. Praktiese Teologie in Suid-Afrika, 8(2):83-94.

LOUW, D.J. 1993b. Praktiese Teologie - 'n fenomenologiese stuiptrekking? Praktiese Teologie in Suid-Afrika, 8(2):206-209.

LOUW, J.P. \& Stander, H.F. 1981. Paulus se 'doring in die vlees'. Nederduitse Gereformeerde Teologiese Tydskrif, 22(4):269-272.

MARSHALL, I.H. 1978. The Gospel of Luke. Exeter : The Paternoster Press.

MINN, H.R. 1972. The thorn that remained. Auckland : Ex Libris.

NIELSEN, J.T. 1983. Het evangelie naar Lucas. Nijkerk : Callenbach.

OUWENEEL, W.J. 1978. Het domein van de slang. Amsterdam : Buijten \& Scipperheijn.

PARKER, R. 1989. The occult. Deliverence from evil. Leicester : Inter-Varsity Press

POTGIETER, F.J.M. 1974. Bonatuurlike verskynsels. Pretoria : N.G. Kerk-Uitgewers.

RENGSTORF, K.H. 1978. Das Evangelium nach Lukas. Gottingen : Vandenhoeck \& Ruprecht. Das Neue Testament Deutsch.

ROSSOUW, P.J. 1992. Besete of siek? 'n Pastoraal-sielkundige perspektief op Satanisme. (In: U.V. teologiese studies nr. 6. Bloemfontein : Pro Christo-Publikasies. p. 32-41.)

SCHWEIZER, E. 1984. The good news according to Luke. Translation: D.E. Green. Atlanta, Georgia: John Knox Press.

SINODE VAN DIE NED. GEREF. KERK O.V.S. 1995. Handelinge van die Sinode. Bloemfontein : Sendingpers.

SINODE VAN DIE NED. GEREF. KERK SUID-TRANSVAAL. 1993. Ongepubliseerd. Handelinge van die Sinode.

SMIT, J.H. 1992a. Wat is Satanisme? (In: U.V. teologiese studies nr. 6. Bloemfontein : Pro Christo-Publikasies. p. 1-8.)

SMIT, J.H. 1992b. Die evangeliebediening aan demonies (okkult) gekweldes (In: U.V. teologiese studies nr. 6. Bloemfontein : Pro Christo-Publikasies. p. 42-51.)

SMIT, M.M. 1981. Die vrylating van gevangenes. Silverton : Dieper Lewe Uitgewers.

TASKER, R.V.G. 1981. 2 Corinthians. Leicester : Inter-Varsity Press.

THERON, J.P.J. 1993. 'n Kritiese bespreking van D.J. Louw se diagnostiese kriteria vir die evaluering van Satanisme in die pastorale bediening. Praktiese Teologie in Suid-Afrika, 9(2):201-216.

THURNEYSEN, E. 1963. A theology of pastoral care. Virginia : John Knox Press.

VAN BRUGGEN, J. 1993. Lucas. Het evangelie als voorgeschiedenis. Kampen : Kok.

WIEFEL, W. 1988. Das Evangelium nach Lukas. Berlin : Evangelische Verlaganstalt.

WILSON, G.B. 1979. 2 Corinthians. Edinburgh : The Banner of Truth. 